\title{
Barbara Szatur-Jaworska
}

ORCID: 0000-0003-3677-000X Uniwersytet Warszawski Wydział Nauk Politycznych i Studiów Międzynarodowych ${ }^{1}$

\section{Polityka spoteczna i zdrowotna w kontekście przebiegu życia cztowieka}

\author{
Stanisława Golinowska, Marzena Tambor (2020), \\ O tączeniu spraw zdrowotnych $i$ społecznych $w$ przebiegu życia, \\ Warszawa: Wydawnictwo Naukowe PWN, 261 s.
}

Opublikowana przez Wydawnictwo Naukowe PWN książka Stanisławy Golinowskiej i Marzeny Tambor pt. O tączeniu spraw zdrowotnych $i$ spotecznych $w$ przebiegu życia jest oryginalną i wartą dostrzeżenia propozycją analizy stanu zdrowia i różnych przejawów społecznego funkcjonowania ludzi w toku ich życia. W analizie tej autorki uwzględniają wpływ różnych instytucji przyczyniających się za zaspokajania ludzkich potrzeb i do rozwiązywania lub łagodzenia problemów społecznych. Jest to podręcznik akademicki, z którego korzystać mogą słuchacze różnych kierunków studiów, w których programach występują zagadnienia polityki zdrowotnej i zdrowia publicznego, polityki społecznej i innych polityk publicznych oraz socjologii problemów społecznych. Przy czym autorki najbardziej eks-

1 Correspondence: Katedra Metodologii Badań nad Polityką WNPiSM UW, ul. Nowy Świat 67 (p. 108, 109), 02-927 Warszawa, author's email address: b.szatur-jaworska@uw.edu.pl 
ponują podejście z punktu widzenia dwóch dyscyplin naukowych: nauk o zdrowiu oraz polityki społecznej.

Struktura publikacji zbudowana została wokół kolejnych etapów przebiegu życia człowieka, a dokładnie rzecz biorąc - wokół subpopulacji przeżywających owe etapy. W poszczególnych rozdziałach omawiana jest zatem sytuacja następujących kategorii społeczno-demograficznych: dzieci, młodzieży, młodych dorosłych, osób będących na etapie późnej dorosłości oraz osób starszych. Rozdziały te poprzedza wprowadzenie do książki oraz dwa rozdziały poświęcone założeniom teoretycznym i - w niewielkim zakresie — metodologicznym związanym z perspektywą przebiegu życia oraz zagadnieniom integracji i koordynacji spraw społecznych i zdrowotnych. Struktura książki jest więc bardzo przejrzysta i logiczna.

„Przebieg życia” jest, jak wiadomo, pojęciem występującym w literaturze naukowej obok takich terminów, jak „bieg życia” oraz „cykl życia”. Granice między nimi są nieostre, a często są one traktowane nawet jako synonimy. Autorki omawianej publikacji zdecydowały się na zastosowanie pojęcia „przebieg życia”, choć bywa, że posługują się także określeniem „cykl życia”. Nie podają definicji tych pojęć, jakie przyjmują dla potrzeb swojej pracy. Omawiają jednak syntetycznie, jak w naukach o zdrowiu i w naukach społecznych charakteryzuje się cykl i przebieg życia oraz jakie są najważniejsze założenia perspektyw badawczych powiązanych z tymi kategoriami.

Obok kategorii przebiegu życia, autorki odwołują się swoim wykładzie do jeszcze innych pojęć, jakie wykorzystują, analizując sytuację poszczególnych subpopulacji. Są to: potrzeby, problemy społeczne i instytucje.

O potrzebach autorki piszą, przywołując przede wszystkim teorię Abrahama Maslowa, głoszącą koncepcję ich hierarchicznego porządku, ale uwzględniają także holistyczne podejście do potrzeb - charakterystyczne dla nauk o zdrowiu. Autorki przyjmują założenie, że w wyniku biologicznego i społecznego rozwoju człowieka poszczególne etapy życia charakteryzuje inna hierarchia potrzeb. I tak, kluczowymi - z punktu widzenia polityki społecznej - są: dla dzieciństwa — potrzeby opiekuńcze, wychowawcze i edukacyjne, dla młodości - wychowawcze, edukacyjne, tożsamościowe i emocjonalne, dla wczesnej dorosłości - mieszkaniowe, relacji intymnych, prokreacji, samorealizacji zawodowej, dla późnej dorosłości — zdrowotne, psychologiczne, edukacyjne (kształcenie permanentne), zaś dla starości — zdrowotne, aktywności społecznej i opiekuńcze. Zaproponowana przez autorki koncepcja pokrywa się z dominującym sposobem myślenia o poszczególnych etapach życia. Pewne decyzje autorek mają jednak charakter dyskusyjny. Na przykład, zdaniem recenzentki, w okresie dzieciństwa do kluczowych należą potrzeby zdrowotne, gdyż od kondycji zdrowotnej na tym etapie życia w znacznym stopniu zależy stan zdrowia na kolejnych etapach biografii ludzi. Wątpliwości budzi także pominięcie dla okresu późnej dorosłości (wiek między 45 a 65/67 lat) potrzeby samorealizacji zawodowej, skoro jest to dla większości osób dorosłych okres wysokiej aktywności zawodowej i — co więcej — w polityce społecznej różnych krajów dąży się do wydłużenia czasu pracy zawodowej.

Problem społeczny został w książce zdefiniowany jako „niezaspokojenie czy nierespektowanie potrzeb społecznych określonej grupy ludności, jeśli ten brak obniża potencjał rozwo- 
jowy osób przynależnych do tej grupy i jest poza ich kontrolą, a jednocześnie, mając znaczny zasięg, pogarsza jakość funkcjonowania całego społeczeństwa” (s. 12). Warto zauważyć, że jest to definicja bliska temu, jak Jan Danecki definiował w swoich pracach teoretycznych pojęcie „kwestia społeczna”. Rozumienie problemu społecznego jest zatem w recenzowanej książce osadzone w teorii polityki społecznej, choć nie można znaleźć tam odwołań do dorobku Jana Daneckiego i jego uczniów. Dodajmy, że w socjologii silny jest nurt teoretyczny, w którym eksponuje się znaczenie, jakie dla wyłaniania się problemu społecznego ma uznanie jakiegoś zjawiska za problem przez różne podmioty tworzące społeczeństwo. Jak się wydaje, autorki podręcznika przyjęły, że problemy społeczne rozpoznają i definiują instytucje realizujące polityki publiczne $\mathrm{w}$ ramach określonego modelu welfare state. Jest to podejście zawężające, ale zrozumiałe w ramach przyjętej w tej książce konwencji.

W omawianej publikacji wiele uwagi poświęcono bowiem instytucjom welfare state. Przede wszystkim w kontekście ,analizowania i oceny systemu z punktu widzenia zdolności do unikania problemów [społecznych] i zapobiegania im oraz umiejętności ich zwalczania i łagodzenia, gdy występują" (s. 12). Za pożądaną cechę tych instytucji autorki uznają ich zdolność nie tylko do łączenia działań, ale także do koordynacji i integracji. Zagadnieniom tym poświęcono osobny rozdział książki, który zamyka autorska propozycja modelu integracji/koordynacji polityki społecznej i zdrowotnej. Jego opracowaniu przyświeca słuszny pogląd, że „efektywne łączenie spraw społecznych i zdrowotnych w wyróżnionych grupach populacyjnych wymaga odejścia od tzw. zarządzania silosowego i doprowadzenia do przełamania barier resortowych, a w naszym przypadku - likwidowania instytucjonalnych barier między sektorem zdrowotnym a sektorami społecznymi” (s. 50). Te ograniczenia we współpracy instytucjonalnej są omawiane na konkretnych przykładach w kolejnych rozdziałach książki.

W rozdziale trzecim, poświęconym problemom zdrowotnym i społecznym dzieci, został scharakteryzowany stan zdrowia dzieci (populacji w wieku od urodzenia do 12-13 lat), ich sytuacja rodzinna (w tym problematyka pieczy zastępczej), materialne podstawy ich rozwoju oraz potrzeby opiekuńcze dzieci. Instytucje odpowiedzialne za zaspokajanie potrzeb dzieci, jakim autorki poświęciły uwagę to głównie przedszkola i szkoły. Nie jest jasne, dlaczego pominięto funkcjonowanie żłobków oraz opieki pediatrycznej. Rozdział zamyka analiza sieci instytucji publicznych odpowiedzialnych w Polsce za zaspokajanie potrzeb dzieci, prowadzona z punktu widzenia możliwości koordynacji ich działań.

Rozdział czwarty dotyczy młodzieży, czyli osób w wieku 11-24 lata. Autorki słusznie dostrzegają zróżnicowanie tej populacji i tego etapu w biegu życia. Omawiają potrzeby i zagrożenia zdrowotne, rolę rodziny, relacje z rówieśnikami, ale także - w stosunku do starszej młodzieży — problemy aktywności zawodowej, edukacji na poziomie wyższym, aktywności społecznej. Uwzględniają także problem ubóstwa rodzin z dziećmi oraz niskich dochodów samych młodych ludzi na etapie ich startu zawodowego. Za rozwiązywanie tych problemów powinna być odpowiedzialna zintegrowana, zorientowana prorozwojowo polityka wobec młodzieży, której brakuje w naszym kraju.

Kolejny etap życia — to wczesna dorosłość. Osobom w wieku 25-44 lata, czyli młodym dorosłym, poświęcony jest rozdział piąty. Ten etap w życiu człowieka rozpoczyna 
następujących „pięć złotych wydarzeń”: ukończenie edukacji, podjęcie regularnej pracy, opuszczenie domu rodzinnego, wejście w związek i narodziny potomstwa (s. 140). Co warto podkreślić, w książce podniesiono problem opóźnień we wchodzeniu w dorosłość, szczególnie w kontekście pozostawania dorosłych dzieci we wspólnych gospodarstwach domowych z rodzicami. Stan zdrowia subpopulacji młodych dorosłych omówiono koncentrując się na stylu życia, prokreacji i warunkach pracy. Główne obszary społecznego funkcjonowania młodych dorosłych, jakimi zajęły się autorki, są praca zawodowa i życie rodzinne. Celem zaś polityki publicznej powinna być koordynacja działań związanych z zatrudnieniem kobiet i mężczyzn, ich stanem zdrowia oraz godzeniem życia rodzinnego $\mathrm{z}$ aktywnością zawodową. W charakterystyce sytuacji młodych dorosłych, zabrakło — zdaniem recenzentki — poszukiwania odpowiedzi na pytanie, jak na tę sytuację rzutują sukcesy i zaniechania polityk publicznych na wcześniejszych etapach życia tych osób oraz jakie konsekwencje w dalszym przebiegu ich życia mogą wywoływać problemy, z jakimi borykają się obecnie.

Rozdział szósty został poświęcony późnej dorosłości, czyli okresowi zaczynającemu się w wieku 45 lat, a kończącemu w chwili osiągnięcia wieku emerytalnego (65/67 lat). Ten etap w życiu jednostek określany jest w statystykach jako wiek produkcyjny niemobilny. W części rozdziału dotyczącej stanu zdrowia autorki skupiły się na zagrożeniach zdrowotnych nasilających się w tym wieku. Jeśli zaś idzie o społeczne funkcjonowanie, omówiły zagadnienia związane z aktywnością zawodową, kształceniem ustawicznym i życiem rodzinnym (m.in. syndrom pustego gniazda, sandwich generation). Zdaniem recenzentki, niesłusznie pominięto społeczną aktywność na etapie późnej dorosłości. Na tym bowiem etapie życia, między innymi dzięki stabilizacji zawodowej i zmianom w życiu rodzinnym, relatywnie wysoki jest poziom społecznego zaangażowania (co pokazują wyniki polskich badań sondażowych). W ostatniej części rozdziału wskazano, jakie powinny być „obszary koordynacji na przedpolu starości”. Autorki nie wskazały natomiast, jakie instytucje welfare state uznają za szczególnie odpowiedzialne za zapewnienie odpowiedniej jakości temu etapowi przebiegu życia.

Zgodnie z przyjęta strukturą wykładu, ostatni rozdział poświęcono etapowi starości. Autorki wyróżniają w nim dwa okresy: trzeci i czwarty wiek (65/67 lat - 80/85 lat oraz 85 lat i więcej). Jednak w charakterystyce sytuacji zdrowotnej osób starszych posługują się najczęściej danymi dla całej tej populacji. Także w analizach sytuacji społecznej to rozróżnienie nie jest konsekwentnie stosowane. Ważne jest, że autorki wiele miejsca poświęcają dobrostanowi i jakości życia w starości. W tym kontekście omawiają życie rodzinne seniorów, kwestię ich aktywności zawodowej i wieku emerytalnego oraz sytuację materialną. W wyniku przyjętego dla całej książki założenia związku „spraw zdrowotnych i społecznych" wiele uwagi poświęcają zagadnieniu aktywnego starzenia się w zdrowiu. Jest to $\mathrm{z}$ jednej strony indywidualna strategia życiowa, a drugiej — cel różnych polityk publicznych. W Polsce polityki te skupiły się w programach i działaniach określanych jako polityka senioralna. Własna propozycja autorek dotycząca koordynacji polityk publicznych wobec osób starszych stanowi podsumowanie rozdziału siódmego. 
Na politykach publicznych koncentrują się autorki w zakończeniu książki, które nosi tytuł „W kierunku rekomendacji”. Syntetycznie omawiają w tej części publikacji problemy społeczne i zdrowotne charakteryzowanych wcześniej grup wieku, wskazując zarazem na braki i niedostatki polityk publicznych. Trzy kluczowe rekomendacje dotyczą zaś: 1) „wzmocnienia wielo- i interdyscyplinarności badań naukowych”; 2) „wzmocnienia perspektywy przebiegu życia w badaniach społecznych i zdrowotnych, jak i uwzględnianie tego podejścia w prowadzeniu polityk publicznych”; 3) ,wzmocnienia instytucji łączenia spraw społecznych i zdrowotnych zarówno w badaniach, jak i programowaniu polityk publicznych" (s. 255).

Recenzowana książka jest przykładem podejścia interdyscyplinarnego do problemów indywidualnych i społecznych, z jakimi zmagają się członkowie współczesnych społeczeństw na różnych etapach życia. Zaprezentowane przez autorki podejście z perspektywy przebiegu życia pozwoliło przede wszystkim na wyeksponowanie problemów osób w różnym wieku (a nie tylko dzieci i osób starszych, którymi najbardziej interesuje się polityka społeczna) oraz na wskazanie wyzwań związanych z przejściami (tranzycją) między kolejnymi etapami ludzkich biografii. Znacznie słabiej udokumentowano natomiast w zaprezentowanym materiale powiązania między różnymi etapami biegu życia, które to powiązania są zarówno „kapitałem” wnoszonym w kolejne etapy drogi życiowej, jak i mogą być źródłem blokad i zagrożeń utrudniających prawidłowy rozwój człowieka i oczekiwane społeczne funkcjonowanie.

Omawiana publikacja jest udaną propozycją interdyscyplinarnego spojrzenia na problemy zdrowotne i społeczne. 